\title{
Assessment of Climate Change by Dendrochronological Methods in Polissya
}

\author{
Iryna Koval ${ }^{1}$, Valentyna Meshkova ${ }^{1}$, Nadiya Maksymenko ${ }^{2}$, Catalin-Constantin Roibu ${ }^{3}$ and Iryna Obolonik ${ }^{1}$ \\ ${ }^{1}$ Ukrainian Research Institute of Forestry and Forest Melioration named after G. M. Vysotsky, Pushkinska, 86, 61024 Kharkiv, \\ Ukraine \\ ${ }^{2}$ V.N. Karazin Kharkiv National University, sq Svoboda, 4, 61022, Kharkiv, Ukraine \\ ${ }^{3}$ Stefan cel Mare University of Suceava, Str. Universitatii, nr. 13, 720229 Suceava, Romania Suceava, Romania
}

\begin{abstract}
Dendrochronological methods were used to study the response of Quercus robur L. to climate change in Polissya. Negative pointer years $(1950,1976,1995,1999,2002,2008$, and 2011) resulted from the precipitation deficiency during the growing season, cold or extremely warm winters, and abnormal early-spring temperatures. Positive pointer years $(1967,1997,2001$, and 2007) had a favorable heat and moisture balance. Dendroclimatic analysis of oak regional tree-ring chronology showed that during the spring and summer terms of 1980 - 2013, as compared to the previous 1946-1979, there a decrease in the positive influence of temperatures on the oak radial growth. In the second period, the negative impact of precipitation during the cold period on radial growth increased. The adverse impact of April precipitation on radial growth for both periods was revealed as well as the positive influence of July precipitation in the first period and precipitation in June and July in the second one. The increased influence of temperatures and precipitation on the oak radial growth in 1980 - 2013, as compared to previous 1946-1979, indicates an increase in the tree sensitivity to climate change in the second period.
\end{abstract}

\section{Introduction}

English oak (Quercus robur L.) is one of the main forest-forming species in Ukraine. Oak forest ecosystems provide a wide range of ecological benefits $[1,2]$. For the early detection of potential dangers, forest growth reactions must be more strongly connected to studies on adaptation relevant characteristics in future. Changes in climate, and weather extremes in particular, are radical selective factors that will change forest structure, including tree species composition, in the future in a regionally differentiated manner. Selectively effective extremes of weather will naturally shift competitive relationships and produce "losers", but also "winners" on all levels of the ecosystem (individual, population, ecosystem, forest community, landscape). Extreme climatic factors will lead to an increased dying off of individual trees within stocks. These trees or groups of trees must be detected early for different measures (timber use, forest protection, prevention of danger to ensure traffic safety etc.) [2].

Given the ecological and economic importance of forest and forestry, an analysis must be made of the potential threat from climate change and adaptation strategies must be developed. According to current knowledge, these observations can only be made for a few decades in advance, which barely represent half of a forest generation. This short time period is unsatisfactory in view of the temporal dimension of forest development [2].

1 Corresponding author: Koval_Iryna@ukr.net
Studying annual rings is essential to investigate English oak adaptation to climate change because they are an integral indicator of the environmental impact on the tree condition [2].

The assumption that the most common causes of forest degradation and large scale deforestation are global climate change and anthropogenic factors is an almost single hypothesis. Therefore discovering specific mechanisms of forest ecosystem development and revealing the causes of forest decline is extremely relevant.

The study aimed to identify the main climatic factors affecting the radial growth of English oak under climate change in Polissya.

\section{Material and methods}

The research was conducted in four sample plots in oak stands aged from 50 to 155 growing in fresh, wet, and moist fertile sites (Table 1, 2).

Table 1 Characteristics of the sample plots in Polissya.

\begin{tabular}{|c|c|c|c|c|}
\hline \multirow[t]{2}{*}{$\begin{array}{l}\mathbf{S} \\
\mathbf{P}\end{array}$} & \multicolumn{2}{|c|}{$\begin{array}{c}\text { GEOGRAPHICAL } \\
\text { LOCATION }\end{array}$} & \multirow[t]{2}{*}{$\begin{array}{c}\text { A S. L., } \\
\text { M }\end{array}$} & \multirow{2}{*}{$\begin{array}{l}\text { SITE } \\
\text { CONDITI } \\
\text { ON }\end{array}$} \\
\hline & $\begin{array}{c}\text { North } \\
\text { latitude }\end{array}$ & $\begin{array}{c}\text { East } \\
\text { longitude }\end{array}$ & & \\
\hline 1 & $50^{\circ} 35^{\prime} 00^{\prime \prime}$ & $27^{\circ} 37^{\prime} 13^{\prime \prime}$ & 218 & $\begin{array}{c}\text { Fresh fertile } \\
\text { site }\end{array}$ \\
\hline 2 & $51^{\circ} 13^{\prime} 40^{\prime \prime}$ & $27^{\circ} 38^{\prime} 53^{\prime \prime}$ & 183 & $\begin{array}{c}\text { Wet } \\
\text { relatively } \\
\text { fertile site }\end{array}$ \\
\hline 3 & $51^{\circ} 13^{\prime} 40^{\prime \prime}$ & $27^{\circ} 38^{\prime} 53^{\prime \prime}$ & 183 & Damp \\
\hline
\end{tabular}




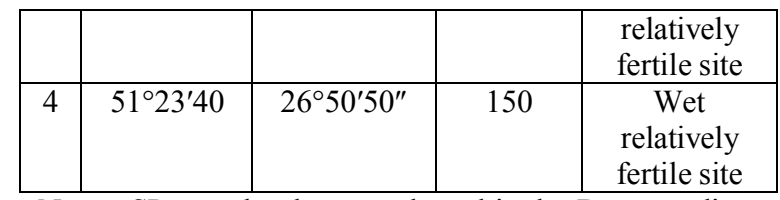

Notes: SP sample plot; a. s. 1. - altitude; D - tree diameter; $\mathrm{H}$-tree height

Table 2. Characteristics of oak stands in Polissya.

\begin{tabular}{|c|c|c|c|}
\hline SP & $\begin{array}{c}\text { AGE, } \\
\text { YEA } \\
\text { RS }\end{array}$ & $\begin{array}{c}\text { DIAMETER, } \\
\text { CM }\end{array}$ & HEIGHT, M \\
\hline 1 & 155 & 44 & 28 \\
\hline 2 & $>100$ & 48 & 26 \\
\hline 3 & $>100$ & 45 & 27 \\
\hline 4 & $>50$ & 26 & 11 \\
\hline
\end{tabular}

We used the data from the Zhytomyr meteorological station $\left(50^{\circ} 15^{\prime} 53^{\prime \prime} \mathrm{N}, 28^{\circ} 40^{\prime} 36^{\prime \prime} \mathrm{E}\right.$, an altitude of $228 \mathrm{~m}$ a. s. 1.).

Standard dendrochronological methods were used [3]. The cores were selected at a breast height $(1.3 \mathrm{~m}$ above the ground). Tree-ring widths were measured using HENSON digital equipment with an accuracy of $0.01 \mathrm{~mm}$. Cross-dating was performed including both counting the tree rings and comparing samples to recognize missing or false rings to identify the exact calendar year for each tree ring formation and reveal errors in the measurements.

The crossdating quality was checked using the COFECHA program [4]. The total signal strength in the series was determined through the intercorrelation coefficient (Rbar.). The coefficient was defined as the mean correlation between all tree-ring chronologies [5]. The expressed population signal (EPS), which states the reliability of measurements in chronology and is a function of Rbar and the number of tree-ring chronologies, was calculated using the formula:

$$
\operatorname{EPS}(t)=\frac{t R b a r}{t R b a r+(1-R b a r)}
$$

Where: $\mathrm{t}$ is the number of tree-ring series;

$\mathrm{R}_{\text {bar }}$ is the mean correlation between tree-ring chronologies.

The suitability of the tree-ring series for further dendroclimatic analysis is evidenced by exceeding the EPS threshold of 0.85 [5].

Standardization of tree-ring chronologies was carried out using the ARSTAN program to remove the age trend. First, a linear approximation was used, and then autoregressive modeling was applied to eliminate the influence of previous years on the formation of the tree ring of the current year. Local chronologies were developed by averaging the values of individual chronologies, and regional chronology was built by averaging the values of local chronologies [3].

The standardization of ring width series allowed us to analyze the response of oak radial growth to climatic factors using the RESPO program from the DPL software package [6]. The response was analyzed for 1946-1979 and 1980-2013 to identify the oak radial growth response to climate variations during these periods. Average monthly temperatures and precipitation amounts from July of the previous year to August of the current year were used. We applied a stepwise regression analysis to select the most growthaffecting climatic factors, as well as a principal component analysis, to remove closely correlated climatic variables from the analysis. Moreover, we used multiple regression analysis to assess climate impact on radial growth [6].

\section{Results and discussion}

A regional tree-ring chronology of English oak for Polissya was built, consisting of 62 individual tree-ring series. The regional chronology was based on four local tree-ring chronologies, which contained 5,119 tree rings. Based on this chronology, the RESIDUAL index series was developed, from which the age trend was removed, making it suitable for dendroclimatic analysis (Fig. 1, Table 3, 4).

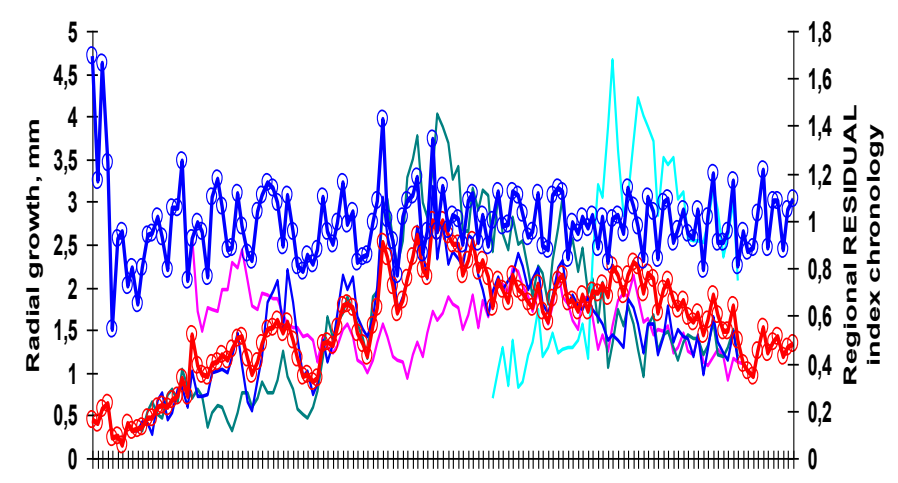

187318831893190319131923193319431953196319731983199320032013

Years

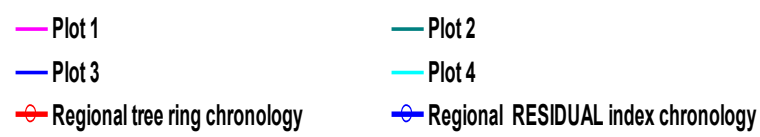

Fig. 1. Dynamics of English oak radial growth and regional RESIDUAL index chronology in stands within Polissya.

Interseries correlation coefficients range from 0.360 to 0.538 , indicating high synchronicity and the possibility of using these tree-ring chronologies to identify the relationships between radial growth and climatic factors (Table 3, 4)

Table 3. Statistical characteristics of local and regional series of tree-ring chronologies of English oak in Polissya according to COFECHA and ARSTAN software.

\begin{tabular}{|c|c|c|c|c|c|c|}
\hline \multirow[b]{2}{*}{ SP } & \multirow{2}{*}{$\begin{array}{c}\text { Pe- } \\
\text { riod, } \\
\text { years }\end{array}$} & \multirow{2}{*}{$\begin{array}{c}\text { Ave- } \\
\text { rage } \\
\text { mm }\end{array}$} & \multicolumn{4}{|c|}{ Tree-ring series } \\
\hline & & & $\mathbf{R}_{\text {bar. }}$ & $\mathbf{S}_{\text {td.dev }}$ & $\begin{array}{c}\mathrm{AC} \\
1\end{array}$ & $\mathbf{M S}_{\mathbf{x}}$ \\
\hline 1 & $\begin{array}{c}1890- \\
2013\end{array}$ & 1.45 & 0.36 & 0.60 & 0.72 & 0.21 \\
\hline 2 & $\begin{array}{c}1897- \\
2002\end{array}$ & 1.97 & 0.54 & 1.12 & 0.83 & 0.25 \\
\hline 3 & $\begin{array}{c}1873- \\
2002\end{array}$ & 1.77 & 0.53 & 0.77 & 0.76 & 0.24 \\
\hline 4 & $\begin{array}{c}1953- \\
2002\end{array}$ & 2.76 & 0.52 & 1.23 & 0.72 & 0.24 \\
\hline
\end{tabular}




\begin{tabular}{|c|c|c|c|c|c|c|}
\hline RT & $1870-$ & 1.86 & 0.40 & 0.87 & 0.76 & 0.24 \\
RS & 2013 & & & & \\
\hline
\end{tabular}

Notes: SP sample plot Rbar. - icorrelation coefficient; $S_{t d . d e v}$ standard deviation; $\mathrm{AC}_{1}-$ first-order autocorrelation; $\mathrm{MS}_{\mathrm{x}}-$ mean sensitivity; RTRS - regional tree-ring series.

Table 4. Statistical characteristics of local and regional RESIDUAL series of tree-ring chronologies of English oak in Polissya according to COFECHA and ARSTAN programs.

\begin{tabular}{|c|c|c|}
\hline \multirow{2}{*}{ SP } & \multicolumn{2}{|c|}{ Residual series } \\
\cline { 2 - 3 } & $\mathbf{M S}_{\mathbf{x}}$ & $\mathbf{S}_{\text {td.dev }}$ \\
\hline 1 & 0.11 & 0.12 \\
\hline 2 & 0.21 & 0.19 \\
\hline 3 & 0.23 & 0.21 \\
\hline 4 & 0.17 & 0.17 \\
\hline RTRS & 0.15 & 0.16 \\
\hline
\end{tabular}

High values of first-order autocorrelation (0.7160.832 ) indicate a high dependence of the current year's tree-ring width on that of the previous year. The EPS coefficient calculated for the regional RESIDUAL treering chronology is 0.98 . This also confirms the possibility of dendroclimatic analysis because it exceeds the threshold of 0.85 , meaning the reliability of the chronology [5]. Sensitivity coefficients exceed 0.2 , which allows this tree-ring chronology to be used in the dendroclimatic analysis (Table 2).

The use of the above factors to determine the reliability of the dendrochronological series has been proven by several studies $[5,7]$. The stand growing in fresh relatively fertile site conditions (SP1) appeared to be the most resistant to the influence of environmental factors, while the stand growing in wet relatively fertile sites (SP 2) was the least resistant. This was confirmed by the values of standard deviation and mean sensitivity, which was the smallest for SP 1 and the largest for SP 2 (Tables 1, 2).

For the period 1873-2014, 23 pointer years in the regional RESIDUAL chronology were defined: 16 negative and 7 positive ones. They comprise about $11 \%$ of the total number of years analyzed. The pointer years of minimal growth $(1950,1976,1995,1999$, 2002,2008 , and 2011) were mainly conditioned by the deficiency in precipitation during the growing season when rainfall deviation from the norm ranged from 33 to $77 \%$ (Fig. 1, table. 3).

In 1976, the precipitation deficiency, cold winter, and early spring temperatures caused a radial growth depression. The deviation from the norm at that time was $52 \%$ for winter temperatures, while March temperatures were almost four times below the norm (Table 5).

During the growing season in 1976, 1995, and 1999 , temperatures in some months exceeded the norm by $37-56 \%$. Due to the temperature increase during the winter period, the radial growth minimums were observed in 1995, 1999, 2002, and 2008 (deviations from the norm were $37-78 \%$ ) (Table 5).

In March of 1995, 1999, 2002, 2008, and 2011, when xylogenesis started, temperatures increased 4-12 times compared to normal (norm was $0.33^{\circ} \mathrm{C}$ ), and March temperatures ranged from 1.2 to $4.3^{\circ} \mathrm{C}$, which could exceed the optimal limit for radial growth of trees (Table 5).
Table 5. Negative pointer years of the regional tree ring chronology of English oak in Polissya

\begin{tabular}{|c|c|}
\hline $\begin{array}{l}\text { Pointer } \\
\text { years }\end{array}$ & Causes of radial growth depression \\
\hline $\begin{array}{l}1877, \\
1926\end{array}$ & $\begin{array}{l}\text { The causes of radial growth depression are } \\
\text { unknown due to the lack of meteorological data }\end{array}$ \\
\hline 1950 & $\begin{array}{l}\text { Radial growth was limited by precipitation in } \\
\text { March-June. In } 1950 \text { the precipitation during this } \\
\text { period was } 90 \mathrm{~mm} \text {, i.e. } 57 \% \text { less than the norm, } \\
\text { with was } 207 \mathrm{~mm}\end{array}$ \\
\hline 1976 & $\begin{array}{l}\text { Cold winter: average winter temperature was }-5.9 \\
{ }^{\circ} \mathrm{C} \text {; the rate was }-3.9^{\circ} \mathrm{C} \text {, i.e. the temperature was } \\
52 \% \text { lower than rate. In March the temperature } \\
\text { was almost four times below the rate: }-1.2^{\circ} \mathrm{C} \text { vs } \\
\text { normal } 17.1 \text {. } \\
\text { Precipitation deficiency was observed in May- } \\
\text { July; the precipitation was } 40 \% \text { less than norm: } \\
\text { the amount was } 132.8 \mathrm{~mm} \text { during these months, } \\
\text { while the norm was } 221 .\end{array}$ \\
\hline 1995 & $\begin{array}{l}\text { Warm winter, during with temperatures were } \\
\text { almost twice as high as the norm: average winter } \\
\text { temperature was }-3.9^{\circ} \mathrm{C} \text {, while the norm was }-1.6 \\
{ }^{\circ} \mathrm{C} \text {. March temperature was eight times higher } \\
\text { than normal: } 2.6^{\circ} \mathrm{C} \text { at a norm of } 0.33^{\circ} \mathrm{C} \text {. In the } \\
\text { summer months, precipitation was } 40 \% \text { below } \\
\text { normal: } 145 \mathrm{~mm} \text { vs } 242 \mathrm{~mm} \text {, respectively. }\end{array}$ \\
\hline 1999 & $\begin{array}{l}\text { The extremely warm period from January to } \\
\text { February, when the temperature was } 55 \% \text { above } \\
\text { normal }\left(-2.05{ }^{\circ} \mathrm{C} \text { vs }-4.6^{\circ} \mathrm{C} \text {, respectively). March }\right. \\
\text { temperature was eight times higher than normal: } \\
2.8^{\circ} \mathrm{C} \text { at a norm of } 0.33^{\circ} \mathrm{C} \text {. During May-July, } \\
\text { precipitation was } 37 \% \text { below the norm: } 136 \mathrm{~mm} \\
\text { at a norm of } 221 \mathrm{~mm} \text {. }\end{array}$ \\
\hline 2002 & $\begin{array}{l}\text { Extremely warm winter, when the temperature } \\
\text { was } 37 \% \text { above normal }-2.5{ }^{\circ} \mathrm{C} \text { at a norm of - } \\
3.9^{\circ} \mathrm{C} \text {. The precipitation deficiency in January, } \\
\text { March, May, and July fluctuated within } 40-53 \% \text {, } \\
\text { i.e. the precipitation were } 19.6 \mathrm{~mm} \text { vs } 56.6 \mathrm{~mm} \text {, } \\
\text { and } 4.4 \mathrm{mmvs} 86.8 \mathrm{~mm} \text {, respectively. March } \\
\text { temperature s was } 12 \text { times higher than normal: } \\
4.2^{\circ} \mathrm{C} \text { vs } 0.33^{\circ} \mathrm{C} \text {, respectively. Dry growing } \\
\text { season, when } 210 \mathrm{~mm} \text { of rain fell during April- } \\
\text { August, i.e. precipitation was } 20 \% \text { below the } \\
\text { norm, with was } 253 \mathrm{~mm} \text {. July was the driest when } \\
\text { precipitation was } 56 \% \text { below normal. }\end{array}$ \\
\hline 2008 & $\begin{array}{l}\text { Warm winter, when temperature exceed the norm } \\
\text { by } 78 \%: 0.8 \%{ }^{\circ} \mathrm{C} \text { at a norm of }-3.9^{\circ} \mathrm{C} \text {. March } \\
\text { temperature was almost four times normal: } 1.2^{\circ} \mathrm{C} \\
\text { vs normal } 0.33{ }^{\circ} \mathrm{C} \text {. Precipitation deficiency: } \\
\text { precipitation during June -August was } 95.4 \mathrm{~mm} \text { at } \\
\text { a norm of } 242 \mathrm{~mm} \text {, i.e. it was } 78 \% \text { below normal. }\end{array}$ \\
\hline 2011 & $\begin{array}{l}\text { March temperature was } 13 \text { times normal: } 4.3^{\circ} \mathrm{C} \\
\text { vs } 0.33^{\circ} \mathrm{C} \text {, respectively. Precipitation deficiency: } \\
\text { during January, March and August deviations } \\
\text { from the norms ranged from } 33 \text { to } 71 \%: 19.2 \mathrm{~mm} \\
\text { vs } 32.7,9.5 \mathrm{~mm} \text { vs } 32.7 \mathrm{~mm}, 32.2 \mathrm{~mm} \text { vs } 56.7 \text {, } \\
\text { and } 51,6 \mathrm{~mm} \text { vs } 77.7 \mathrm{~mm} \text {, respectively }\end{array}$ \\
\hline
\end{tabular}

Thus, the pointer years of minimal growth (1950, 1976, 1995, 1999, 2002, 2008, and 2011) resulted from the precipitation deficiency during the growing season, cold or extremely warm winters, and early spring temperatures.

The favorable heat and moisture balance for tree growth was found during the positive pointer years: 1875, 1902, 1906, 1912, 1967, 1997, 2001, and 2007. In 1967, the precipitation in March-May exceeded the norm by $30 \%: 194.1 \mathrm{~mm}$ at the norm of $129.8 \mathrm{~mm}$. In 
1997, 2001, and 2007, the precipitation in MarchSeptember was almost twice the norm: $564.6 \mathrm{~mm}$, $574.1 \mathrm{~mm}$, and $548.5 \mathrm{~mm}$, respectively, at a norm of $120.7 \mathrm{~mm}$. At the same time, temperature deviations from the norm were insignificant.

The anomalous meteorological years of the Navacerrada (Spain) register have been analyzed in detail with the aim of establishing correlations with the extreme reductions of growth. Given that summer precipitation was found to be the most limiting factor for the radial growth of Pinus in the middle of the 20th century, it is also an explanatory factor in almost $50 \%$ of the extreme growths. The negative pointer years 1962, 1963 and 1965 correspond with lack of precipitation during growing season in Navacerrada $(1962,1964)$ and were dry throughout Spain, whereas the1986 ring was formed after the dry year of 1985. Meanwhile, the positive 1959, 1973 and 1976 pointer years correspond with wet years. Nevertheless, other positive pointer years identified in the chronologies of the Sierrade Guadarrama - 1958, 1964, 1980 and 1994 - do not appear to have any clear climatic explanation, even when taking into account the anomalies during spring. This last-mentioned meteorological variable also to have a significant influence on the width of the rings in Central Spain, and could explain the positive tree radial increment of 1943 and 1945, and also the negative tree radial growth of 1986 . Pointer year of 1996 was connected with extreme reduction in winter temperature. This year was anomalous to the normal development of the cambium, due to the branches breaking under the weight of snow. The period 19901995 is the driest period of the whole meteorological register. The decade of the 1990s was having one of the more extreme droughts that affected a major part of the Peninsula. 1995 is a pointer year related to this driest period [7].

The suitability of pointer years for determining extreme climatic events has been demonstrated by several investigations $[7,8,9,10,11]$. Climatic interpretations, such as hard winter frosts, severe summer droughts, or extremely cold springs, may explain most of the negative pointer years [7, 12]. Conversely, the most positive growth responses resulted from a local combination of favorable environmental factors [11].

Analysis of the response function showed that it is generally accepted that the tree-ring growth response to the climate is constant over time, covering the entire lifespan of trees [3]. However, the assumption that the relationship between tree radial growth and climatic factors is stable over time is doubtful, given the nature of the annual wood layer formation and the possibility that climate and other environmental factors may change over time $[13,14]$.

The oak radial growth response to climate variations was compared for two periods: 1946-1979 and 1980-2013. The average annual temperature of the first period was $6.9^{\circ} \mathrm{C}$ while that of the second one was 7.7. C; namely, there was an increase in temperature by $11 \%$. For the first period, the average annual rainfall was $582 \mathrm{~mm}$, and that for the second one amounted to $629 \mathrm{~mm}$, i.e. the difference was $8 \%$ (Fig. 2).

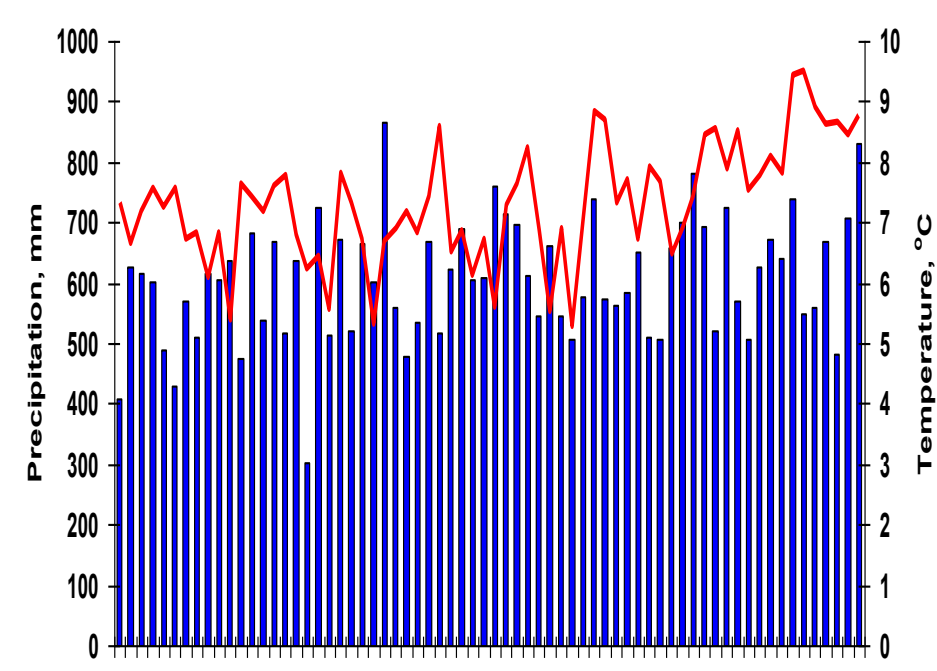

19461951195619611966197119761981198619911996200120062011

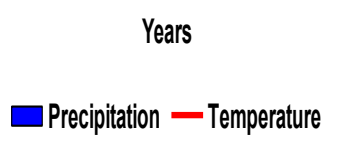

Fig. 2 Dynamics of temperature and precipitation according to the data of Zhytomyr meteorological station

We analyzed the response function for the periods 1946-1979 and 1980-2013. For the first period, the multiple correlation coefficient (R) for temperatures, precipitation and tree-ring indices RESIDUAL was $0.81(F=3.728, \alpha=0.004)$. Temperatures and precipitation determine the radial growth variability by $65.09 \%$. For the second period, the multiple correlation coefficient was calculated: $-0.91(F=7.568, \alpha=$ $0.00004)$. The radial growth variability for oak was $83.10 \%$ dependable on temperatures and precipitation.

Thus, the dependence of radial growth on climatic factors increased in the second period.

Analysis of the response function when comparing the oak radial growth response for 1946-1979 and 1980-2013 showed a decrease in the positive effect of temperatures during the growing season in the second period. For example, for the first period, a significant positive effect of temperatures was recorded in May, July, and August, while for the second period, a positive effect was found only for May and July. The negative effect of temperatures on growth was registered in the first period in June, and in the second period two months earlier, in April (Fig. 3).

"The dendroclimatic analysis showed a similarly positive 'summer response' meaning the summer droughts had an inhibiting effect on the oaks. Water stress is equal to oaks in all vigour classes. Apparently, the sequential droughts during the preceding decade incited the dieback of the declining and the dead trees during 2005-2007. Thus, there appears to be a time lag between the mortality-inducing factors and actual death. Our results differ from the previous study in a lack of clear negative climate 'winter response'. On the seasonal scale, we can admit a favourable spring warmth effect on both early wood and total annual ring growth and a positive effect of mild winter on early wood formation" [18]. 


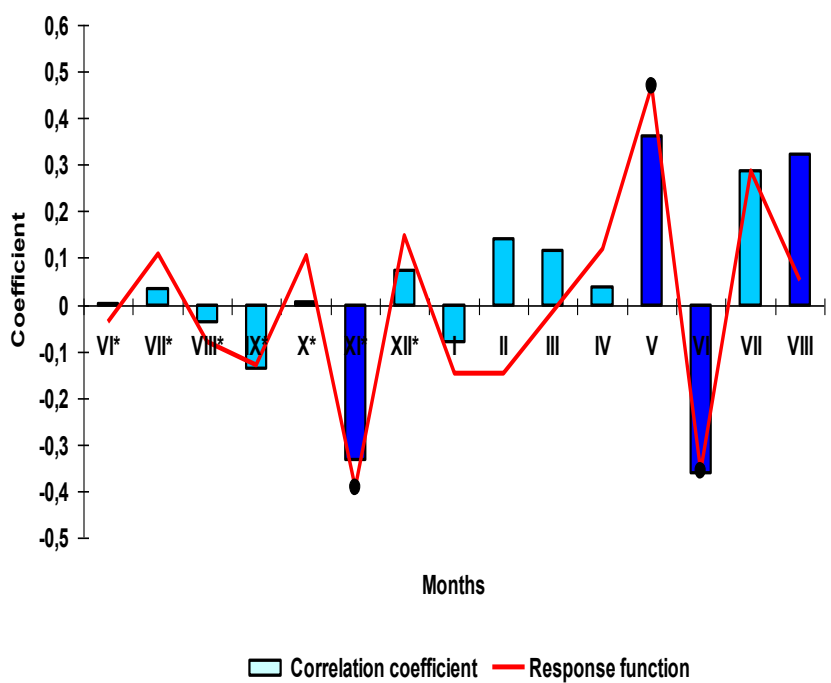

(A) $1946-1979$

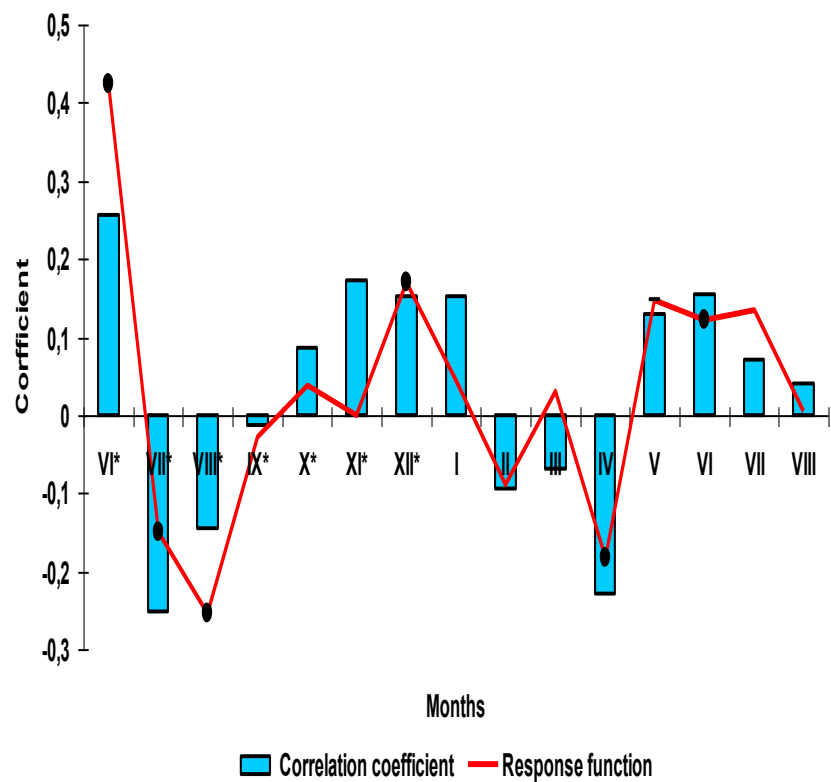

(B) 1980-2013

Fig. 3. Pearson correlation coefficients (bars) and response function coefficients (lines) between average monthly temperatures and regional tree-ring index chronology for Polissya (dark blue bars indicate significant correlation coefficients $(P<0.05)$; black circles show significant response function coefficients; asterisks $(*)$ indicate the month of the previous year)

In the 1980-2013 (second period), the dependence of oak radial increment on precipitation increased. The impact of the previous year's precipitation on growth in the second period increased compared to the first one: negative effect on radial increment in June and November was found as well as positive in July and September, while for the first period there was only a significant negative impact of November precipitation for the previous year. In the spring, April precipitation had a negative influence on the radial growth in the first period, while in the second period there was a negative impact not only in April but also in February.
The positive effect of temperatures was found for June and July in the second period and only for July in the first one (Fig. 4).

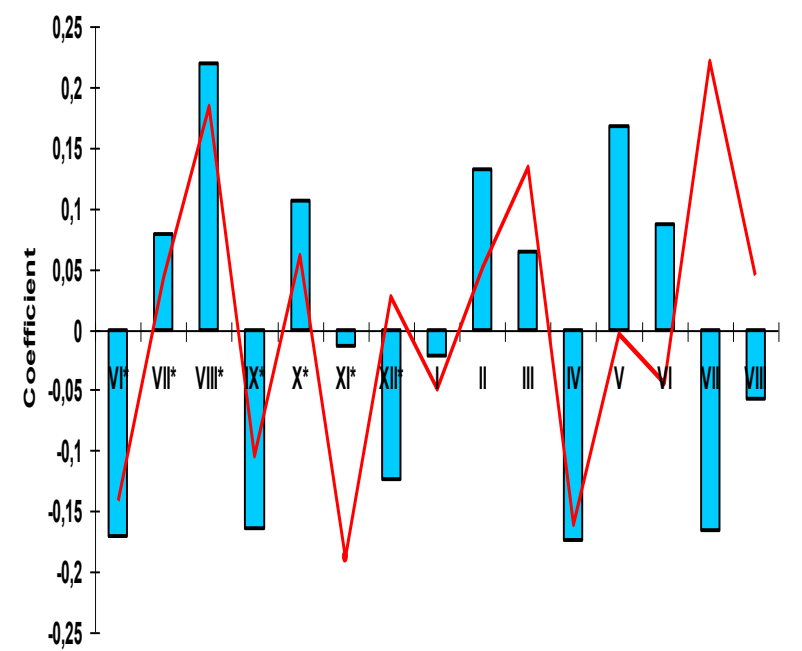

Months

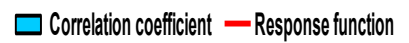

(A) 1946-1979

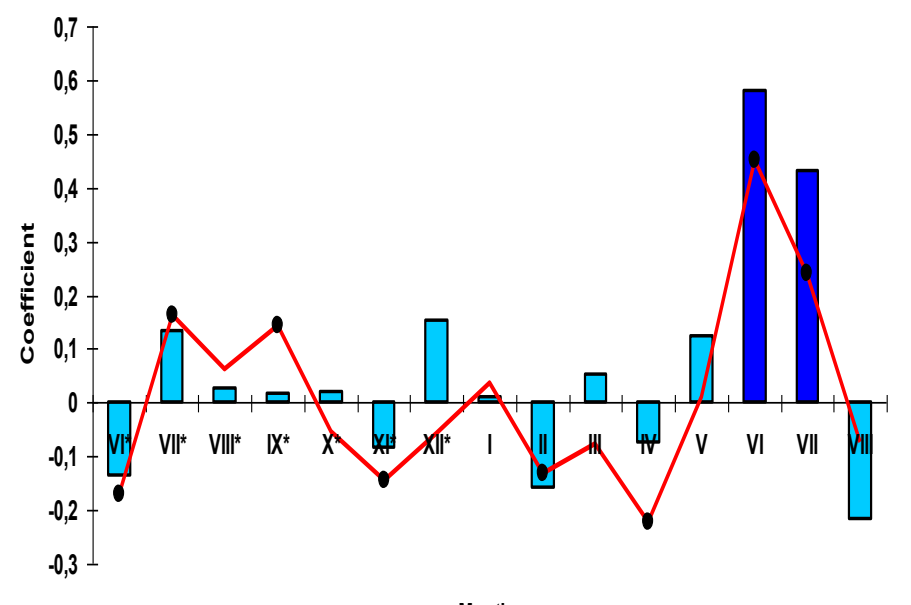

Months

$\square$ Correlation coefficient - Response function

(B) 1980-2013

Fig. 4. Pearson correlation coefficients (bars) and response function coefficients (line) between monthly precipitation and regional tree-ring index chronology for Polissya (dark blue bars indicate significant correlation coefficients $(\mathrm{P}<$ 0.05); circles show significant response function coefficients; asterisks $(*)$ indicate the month of the previous year)

Spring temperatures has weakened, and summer precipitation has more negative influence of the tree radial growth. The temperature - sensitivity of tree rings to spring to winter temperature weakened towards the end of the previous century. It was found that a positive influence of August precipitation and negative impact of July temperature in the previous year on tree ring width appeared. Climate change has led to lower sensitivity of oak tree rings to winter 
temperature. Radial growth of trees in stands growing in the eastern region of Latvia, can be limited by summer droughts [17].

It was investigated the decline of Quercus robur L. growing on shallow soil at the northern distributional limit of the species in southern Finland, using the dendroclimatic methods. Oak radial increment was positively related to the June and July precipitations. This was expressed more influenced by the warmer winter and spring. It was detected that the dead oaks and the declining oaks had caused growing during 2005-2007 after a decade-long summer drought series. The radial increment of the declining and the dead trees had dropped already since the 1990s, while the healthy oaks had better long-term growth and higher adaptive capacity to climate variation [18].

Hungarian researchers found a enough strong response of the oak tree rings to precipitation during the growing season, and negative correlations with late spring temperatures since the early 1960s [15], as in our study.

It was investigated that in central Italy drought in MayJune and in prior-year summer and autumn was negatively influenced on the radial increment during 1974-2006. November precipitation had strong signal in the tree ring series. Moving Correlation Functions (11 y windows) indicated that the May-June signal remained dominant until 1996, thereafter falling to non- significant values in parallel with the May-June water balance drying trend; the previous autumn correlations had significant values. Since 1994 there was a two-year lagged response to June water balance, suggesting that, when growth declined, loss of currentyear climate signals was accompanied by the emergence of previous-year ones. Growth and productivity of deciduous oaks in Mediterranean conditions is linked to spring and summer precipitation; oak growth decline was associated with a delayed response to climate [16].

In Latvia it was found that changes in response of wood formation in English oak to climatic factors since 1900. It was hypothesised that the effect of winter and negative pointer years $(1950,1976,1995,1999,2002$, 2008, and 2011) resulted from the precipitation deficiency during the growing season, cold or extremely warm winters, and abnormal early-spring temperatures. Positive pointer years $(1967,1997,2001$, and 2007) had a favourable temperature and precipitation for growth of trees. It was found that the increased influence of temperatures and precipitation on the oak radial growth increased that tells about strengthening in the tree sensitivity to climate change [17].

It was investigated the decline of a oak (Quercus robur L.) forest growing on shallow soil at the northern distributional limit of the species in southern Finland, using the dendroclimatic methods. Radial increment of oak was positively related to the June and July precipitations. This was expressed more influenced by the warmer winter and spring. The analyses showed that the dead oaks and part of the declining oaks had ceased growing during 2005-2007 after a decade-long summer drought series. This indicates a time lag in the oak dieback. The radial growth of the declining and the dead oaks had dropped already since the 1990s, while the healthy oaks had better long-term growth and higher adaptive capacity to climate variation [18].

\section{Conclusion.}

A regional tree-ring chronology of English oak for Polissya was built, consisting of 62 individual tree-ring series. The regional chronology was based on four local tree-ring chronologies.

The response function for the periods 1946-1979 and 1980-2013 detected that for the first period, temperatures and precipitation determine the radial growth variability by $65.09 \%$. For the second period, the radial growth variability for oak was $83.10 \%$ dependable on temperatures and precipitation.

Negative pointer years $(1950,1976,1995,1999,2002$, 2008, and 2011) resulted from the precipitation deficiency during the growing season, cold or extremely warm winters, and abnormal early-spring temperatures. Positive pointer years $(1967,1997,2001$, and 2007) had a favorable heat and moisture balance.

The increased influence of temperatures and precipitation on the oak radial growth in 1980-2013, as compared to previous 1946-1979, indicates an increase in the tree sensitivity to climate change in the second period.

\section{References}

1. Lakyda П. I., R.V. Sendzjuk, O.V. Morozjuk. Forests of Poltava region: bioproductivity and dynamics, 219 (2011)

2. K. Höppner, R. Kätzel. For Pol. A 53, 9 (2011).

3. E.R. Cook, L.A. Kairiukstis. Methods of Dendrochronology. Applications in the Environmental Sciences, 394 (1990)

4. H.D. Grissino-Mayer. Tree-Ring Res. 57, 16 (2001)

5. T. M. Wigley, K. R Briffa., P. D. Jones. J. Climate Appl. Meterol. 23, 12 (1984).

6. R.L. Holmes. Dendrochronology program library users manual. Laboratory of Tree-Ring Research, 51 (1994)

7. M. Génova., Clim. Past. 8, 13 (2011)

8. B. Neuwirth, F. H. Schweingruber, M. Winiger. Dendrochronologia. 24, 10(2007)

9. F. Kienast, F. Schweingruber, O. Braker, E Schar. Can. J. Forest. Res. 17, 13 (1987)

10. F.H. Schweingruber, D. Eckstein, F. Serre-Bachet, O.U. Braker. Dendrochronologia. 8, 29 (1990)

11. C. Rolland, C. Desplanque, R. Michalet, F. H Schweingruber: Arct. Antarc. Alpine Res. 32, 12 (2000).

12. I. Koval. Baltic Forestry. 19(2), 6 (2013)

13. V. Rozas Annals of Forest Science. 62, 9 (2005).

14. H. Visser, J. Molenaar. Journal of Climate. 8, 10 (1995) 
15. M. Árvai, A. Morgós, Z. Kern. Biogeosciences and Forestry. 11 (2), 7 (2018)

16. Di Filippo, A. Alessandrini, F. Biondi, et al.. Ann. For. Sci. 67, 706 (2010).

17. Ā Jansons, R. Matisons, L Purina., U Neimane., J.Jansons (2015). Silva Fen. 49, 12 (2015)

18. K. Sohar, S.i Helama, A. Läänelaid, J.Raisio, and

H. Tuomenvirta. Geochronometria. 41(1), 11 (2014). 